\title{
Computational model of midbrain dopaminergic neuron activity in ageing and obesity
}

\author{
Svitlana Popovych ${ }^{1 *}$, Ursel Collienne ${ }^{2}$, Simon Hess ${ }^{2}$, Peter Kloppenburg ${ }^{2}$, Silvia Daun-Gruhn ${ }^{1}$ \\ From Twenty Second Annual Computational Neuroscience Meeting: CNS*2013 \\ Paris, France. 13-18 July 2013
}

Obesity is an increasing health problem in the modern world. Feeding behavior is mostly controlled by homeostatic and hedonic systems. It was already demonstrated in the hypothalamus that diet-induced obesity can change the spontaneous activity of cells involved in homeostatic regulation. It is, however, unclear if the hedonic regulation is also affected by diet-induced obersity. The midbrain dopaminergic (DA) neurons are a key component of the hedonic system. Usually, dopaminergic neurons in brain slice preparations show a highly regular pacemaker-like activity pattern. However it was found in [1], that in mice fed on high fat diet (HFD) a significantly increased proportion of DA neurons fired irregularly as compared to the ones in mice that ware fed on normal diet (NCD). A mathematical model of midbrain dopaminergic neuron (DA) has been developed to better understand the mechanisms underlying the different types of firing patterns that these cells exhibit in vitro. The dopaminergic neuron was modeled using a single compartment which includes voltage and $\mathrm{Ca}^{2+}$-dependent currents described by Hodgkin-Huxley kinetics. The model used in this study is based on an existing DA neuron model [2,3] and some parameters were determined using new voltage-clamp data from HFD and NCD mouse brain slices.

\footnotetext{
Author details

'Emmy-Noether Research Group of Computational Biology, Department of Animal Physiology, University of Cologne, 50674 Cologne, Germany. ${ }^{2}$ Cologne Excellence Cluster on Cellular Stress Responses in AgingAssociated Diseases, Department of Animal Physiology, University of Cologne, 50674 Cologne, Germany.
}

Published: 8 July 2013

\footnotetext{
* Correspondence: spopovyc@uni-koeln.de

'Emmy-Noether Research Group of Computational Biology, Department of Animal Physiology, University of Cologne, 50674 Cologne, Germany

Full list of author information is available at the end of the article
}

References

1. Collienne U: Metabolic Modulation of Dopaminergic Neurons. Master's Thesis, University of Cologne 2012.

2. Li Y-X, Bertram R, Rinzel J: Modelling N-methyl-D-aspartate-induced bursting in dopamine neurons. Neuroscience 1996, 71:397-410.

3. Amini B, Clark J, Canavier CC: Calcium dynamics unterlying pacemakerlike and burst firing oscillations in midbrain dopaminergic neurons: a computation study. J Neorophysiol 1999, 82:2249-2261.

doi:10.1186/1471-2202-14-S1-P85

Cite this article as: Popovych et al: Computational model of midbrain dopaminergic neuron activity in ageing and obesity. BMC Neuroscience 2013 14(Suppl 1):P85.
Submit your next manuscript to BioMed Central and take full advantage of:

- Convenient online submission

- Thorough peer review

- No space constraints or color figure charges

- Immediate publication on acceptance

- Inclusion in PubMed, CAS, Scopus and Google Scholar

- Research which is freely available for redistribution
C Biomed Central 